\title{
A MODIFIED METHOD FOR REMOVAL AND STABILIZATION OF CESIUM METAL IN VITRIFIED MATRIX
}

\author{
Abdul Ghaffar', Farhana Mazhar ${ }^{2}$, Azhar Mashiatullah', \\ Abdulaziz S. Alaamer ${ }^{3}$ \\ ${ }^{1}$ IAD, PINSTECH, P.O. Nilore, Islamabad, Pakistan; \\ ${ }^{2}$ Department of Chemistry Lahore College for Women University, Lahore, \\ Pakistan; \\ ${ }^{3}$ Al-Imam Muhammad Ibn Saud Islamic University, Riyadh, Saudi Arabia
}

Received 07.06.2011

\begin{abstract}
Laboratory experiments were designed to investigate the separation and stabilization of cesium metal. Cesium was removed from simulated waste through sorption under certain physicochemical conditions. Silica sand (locally purchased) was used to remove cesium from simulated liquid waste. The range of $\mathrm{pH}$ and temperature was optimized and maximum removal (94-98\%) of cesium was achieved with pH 10 at temperature $36^{\circ} \mathrm{C}$. Under optimized conditions with temperature range of 301$315 \mathrm{~K} \Delta \mathrm{H}, \Delta \mathrm{S}$ and $\Delta G_{309 \mathrm{~K}}$ for $150 \mathrm{ppm}$ solution are $-27.22 \pm 0.18 \mathrm{KJ} / \mathrm{mol},-74.1 \pm$ $0.96 \mathrm{~J} / \mathrm{mol}$ and $-3071 \pm 2.1 \mathrm{KJ} / \mathrm{mol}$ respectively, and for $200 \mathrm{ppm}$ solution thermodynamic entities are $\Delta H=-20.2 \pm 0.20 \mathrm{KJ} / \mathrm{mol}, \Delta S=-47.86 \pm 0.66 \mathrm{~J} / \mathrm{mol}$ and $\Delta G_{301 K}=-4344 \pm 3.7 \mathrm{KJ} / \mathrm{mol}$. The sorbed metal ion has chances of desorption under changed physicochemical conditions in final disposal. To overcome this problem the final "secondary waste (metals on sorbents)" was stabilized by converting it into a stable vitreous borosilicate matrix through vitrification process to prevent leaching. It was found that the sorbed cesium was evaporated during heating at $1250^{\circ} \mathrm{C}$. The evaporation of cesium during vitrification was overcome by modifying the process. This modified vitrification process is found excellent to immobilize the sorbed cesium. Stability was tested by desorption attempts at different $p H$.
\end{abstract}

Keywords: cesium removal, borosilicate matrix, leachibility physiochemical conditions, sorption and kinetics, stabilization.

\section{Introduction}

Cesium is used in industry as a catalyst promoter, boosting the performance of other metal oxides in the capacity and for the hydrogenation of organic compounds. Cesium occurs naturally in the environment mainly from erosion and weathering of rocks and minerals. Cesium salts are used to strength various types of glass. Cesium nitrate is used to make optical glasses. Cesium is sometimes used to remove traces of oxygen from the vacuum tubes and from light bulbs. The chloride is used in photoelectric cells, in optical instruments, and in increasing the sensitivity of electron tubes. Cesium is used in atomic 
clocks and more recently in ion propulsion systems. It is released into the air, water and soil through industrial effluents, mining and milling of ores. In water and soils most cesium compounds are very water-soluble. It remains within the top layers of soils as it strongly bonds to soil and silica particles and as a result it is not readily available for uptake through plant roots. Cesium in air can travel long distances before settling on earth. In soils, however, cesium does not rinse out into the groundwater.

Humans may be exposed to cesium by breathing, drinking or eating. Due to this, effects such as nausea, vomiting, diarrhoea and bleeding may occur. When the exposure lasts a long time people may even lose consciousness. Coma or even death may than follow. How serious the effects are depends upon the resistance of individual persons and the concentration a person is taken to [1]. Cesium is not biodegradable like other toxic pollutants and once in the environment, their potential toxicity is controlled by their physiochemical form [2,3]. Soils [4 - 7] and clays [8-11] with aluminosilicates are found to be very selective ion exchangers for many cations and exhibit very high stability, many clays exhibit excellent sorption activity with Montmorillonite as a major constituent. Both the natural and synthetic Zeolites have also been reported for the sorption of cesium [12-14]. The removal is maximized under certain physiochemical conditions therefore there are chances of the desertion of the adsorbed metal ions under changed physiochemical conditions in final disposal. This possibility emphasized the need to stabilize these adsorbed metals ions after sorption. Solidification/stabilization $(\mathrm{S} / \mathrm{S})$ reduces the mobility of hazardous substances and contaminants in the environment through both physical and chemical means. Unlike other remedial technologies, S/S seeks to trap or immobilize contaminants within their "host" medium i.e., sand, that sorbed them).

Due to the large amount of glass network former in sand, it is cheap and a promising basic material for glass. Because of its good chemical durability and inexpensiveness, $\mathrm{S}_{\mathrm{i}} \mathrm{O}_{2}$ is the most widely used glass forming oxides and therefore the major ingredients of glass. Many glass forms of different waste streams have been developed $[15,16]$. The chemical resistance of glass can allow it to remain in a corrosive environment for thousands or millions of years. Other strong reason is that glass has an ability to incorporate the waste contaminates in its microstructures [17]. The silica sand contains $80.361 \%$ $\mathrm{S}_{\mathrm{i}} \mathrm{O}_{2}$, was chosen for adsorption provided a basis from which glass formulation was developed. The cesium metal was sorbed onto the silica sand and then developed into glass frit with required characteristics regarding to its stability. The development of suitable glass without considerable addition of further additives with reasonable melting temperature is an achievement of present work. During vitrification process cesium has tendency to evaporate at temperature above $600^{\circ} \mathrm{C}$ which was overcome by modifying the vitrification 
process. This modified vitrification process is found excellent to immobilize the sorbed cesium. Leachability testing is typically performed to measure the immobilization of contaminants at different $\mathrm{pH}$ and temperature.

\section{Experimental}

Silica sand (Locally purchased) was washed twice with distilled water after washing with dilute $\mathrm{HCl}$ and dried in air. The composition of silica sand (Table 1) was analyzed by inductively couple plasma spectrometry (ICP) and $\mathrm{X}$-ray diffractions technique. An assembly of glass columns was used for the sorption treatment with dimensions of,inner diameter $2.3 \mathrm{~cm}$, bed height $15.7 \mathrm{~cm}$, volume $68 \mathrm{~cm}^{3}$. The weight of the silica sandfilled in column was $18.64 \mathrm{~g}$. For sorption treatment the effluents were allowed to pass through the glass columns packed with silica sand. The removal efficiency of adsorbent was maximized by varying $\mathrm{pH}$ of samples and temperature.

Table 1. Chemical composition of silica sand (oxide basis, Wt, \%)

\begin{tabular}{|c|c|}
\hline Oxides & $\mathrm{Wt}, \%$ \\
\hline $\mathrm{S}_{\mathrm{i}} \mathrm{O}_{2}$ & 80.361 \\
\hline $\mathrm{Al}_{2} \mathrm{O}_{3}$ & 5.301 \\
\hline $\mathrm{CaO}$ & 4.369 \\
\hline $\mathrm{Fe}_{2} \mathrm{O}_{3}$ & 2.988 \\
\hline $\mathrm{M}_{\mathrm{g}} \mathrm{O}$ & 1.456 \\
\hline $\mathrm{Na}_{2} \mathrm{O}$ & 1.232 \\
\hline $\mathrm{K}_{2} \mathrm{O}$ & 1.101 \\
\hline $\mathrm{MnO}$ & 0.053 \\
\hline $\mathrm{ZnO}$ & 0.004 \\
\hline
\end{tabular}

Silica sand was carefully introduced from the top, continuous tapping ensured the uniform packing up to desired level. The known volume of 150 and $200 \mathrm{ppm}$ solution of cesium (prepared from cesium nitrate) were run through the column packed with sorbent.

The effluent was collected from the bottom in plastic bottles and again analyzed for the concentration of cesium. The change in the concentration of cesium after treatment was calculated by taking difference between two 
concentrations. The concentration of cesium ions in solutions was measured by atomic absorption spectrophotometer (Hitachi Z-2000) equipped with hollow cathode lamp of cesium. The percentage sorption (R, \%) and distribution coefficient $\left(\mathrm{K}_{\mathrm{d}}\right)$ was calculated using following relationship:

$$
\begin{array}{r}
\mathrm{R}=\frac{\mathrm{C}_{\mathrm{i}}-\mathrm{C}_{\mathrm{t}}}{\mathrm{C}_{\mathrm{t}}} 100 ; \\
\mathrm{K}_{\mathrm{d}}=\left(\frac{\mathrm{C}_{\mathrm{i}}-\mathrm{C}_{\mathrm{t}}}{\mathrm{C}_{\mathrm{t}}}\right) \frac{\mathrm{V}}{\mathrm{m}},
\end{array}
$$

where $\mathrm{C}_{\mathrm{i}}$ is the initial concentration ( $\mathrm{ppm}$ ) of the cesium in solution and $\mathrm{C}_{\mathrm{t}}$ concentration of solution after treatment, $\mathrm{V}=$ volume of sorbate $\left(\mathrm{cm}^{3}\right)$ and $\mathrm{m}=$ amount of sorbent $(\mathrm{g})$.

\section{Results and Discussion}

Table 2 showed the effect of $\mathrm{pH}$ of sample on sorption, three different samples were prepared with different $\mathrm{pH}$ values which were as, 2, 4, 7, 10 and 12 using buffer solutions of acetic acid/sodium acetate and ammonium hydroxide/ammonium chloride, respectively. The removal of cesium by sorbents was highly dependent on the $\mathrm{pH}$ of the solution which affects the surface charge of the sorbents, degree of ionization and speciation of the sorbates. Samples with different $\mathrm{pH}$ were passed through columns filled with silica sand. The change in sorption efficiency with change in $\mathrm{pH}$ of samples was found to be significant. The maximum sorption was obtained at $\mathrm{pH} 10$ [18], as shown in Fig.1. The difference in removal efficiency due to the solution $\mathrm{pH}$ was attributed to the precipitation of cesium hydroxide at a higher $\mathrm{pH}$. Increasing the $\mathrm{pH}$ implied a promotional increase of $\mathrm{OH}$ ions concentrations in solution disturbing equilibrium which could be achieved again through formations of greater amount of hydroxide out of the solution.

Table 2. Effect of $\mathrm{pH}$ on the removal of Cs

\begin{tabular}{|c|c|c|c|c|c|c|}
\hline \multirow{2}{*}{$\begin{array}{c}\text { Adsorbing material } \\
\text { (packed in } 2.3 \mathrm{~cm} \varnothing \times \\
15.7 \mathrm{~cm} \text { column) }\end{array}$} & \multirow{2}{*}{$\begin{array}{c}\text { Conc. of } \\
\text { Cs (ppm) }\end{array}$} & \multicolumn{5}{|c|}{ Removal (\%) at $\mathrm{pH}$} \\
\cline { 3 - 7 } & & 2 & 4 & 7 & 10 & 12 \\
\hline \multirow{2}{*}{ Silica Sand } & 150 & 62 & 68 & 85.5 & 9 & 82 \\
\cline { 2 - 7 } & 200 & 64 & 66 & 87 & 9 & 82. \\
\hline
\end{tabular}


Table 3 explained the effect of temperature on sorption. Each sample solution with different temperature i.e. $25^{\circ} \mathrm{C}, 28^{\circ} \mathrm{C}, 32^{\circ} \mathrm{C}, 36^{\circ} \mathrm{C}, 40^{\circ} \mathrm{C}$ and $42^{\circ} \mathrm{C}$ was passed through the sorbents. It was observed that the sorption of cesium was increased with the increase in temperature as reported by [19, 20], and maximum sorption was achieved at $36^{\circ} \mathrm{C}$. The sorption was then decreased as the temperature was increased more than $36^{\circ} \mathrm{C}$ with order as: $42^{\circ} \mathrm{C}<40^{\circ} \mathrm{C}$ $<36^{\circ} \mathrm{C}>32^{\circ} \mathrm{C}>28^{\circ} \mathrm{C}>25^{\circ} \mathrm{C}$.

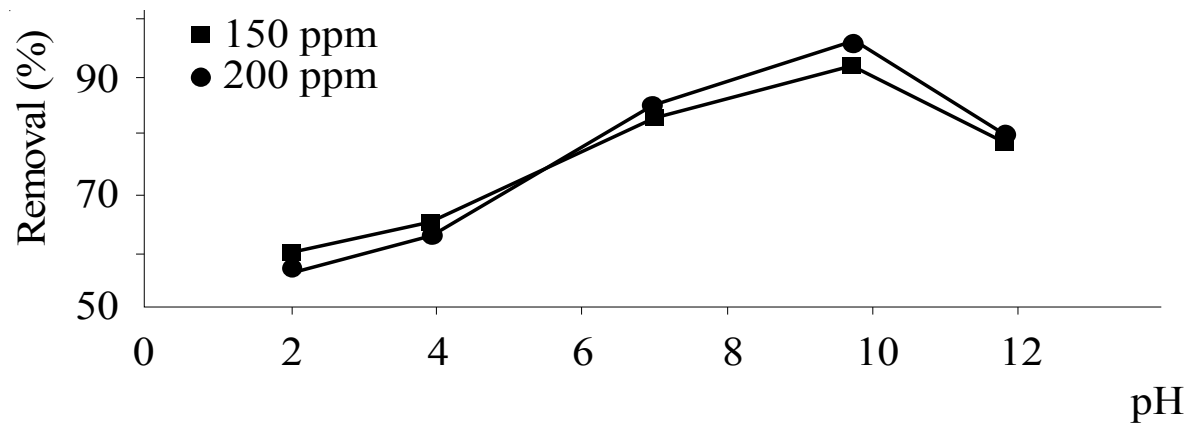

Fig. 1. Removal of Cs at different $p H$.

Table 3. Effect of temperature on removal of Cs

\begin{tabular}{|c|c|c|c|c|c|c|c|}
\hline \multirow{2}{*}{$\begin{array}{l}\text { Adsorbing material } \\
\text { packed in 2.3cm } \varnothing \times \\
15.7 \mathrm{~cm} \text { column) }\end{array}$} & $\begin{array}{c}\text { Conc. of } \\
\text { Cs (ppm) }\end{array}$ & \multicolumn{5}{|c}{ Removal (\%) at temperature } \\
\cline { 3 - 8 } Silica Sand & 150 & 80 & 89 & 90 & 94 & 77 & 70 \\
\cline { 2 - 8 } & 200 & 82 & 90 & 93 & 98 & 80 & 72 \\
\hline
\end{tabular}

The values $\Delta \mathrm{H}, \Delta \mathrm{S}$ were calculated from the slope and intercept of the linear Van't Hoff plot of $\log \mathrm{K}_{\mathrm{c}} \mathrm{Vs} 1 / \mathrm{T}$ where $\mathrm{K}_{\mathrm{c}}=\mathrm{F} / 1-\mathrm{F}$ and $\mathrm{T}$ is absolute temperature in Kelvin and $\mathrm{F}$ represents the fraction sorbed at equilibrium.

The values of $\Delta \mathrm{H}$ and $\Delta \mathrm{S}$ were computed using the relations:

$$
\log \mathrm{K}_{\mathrm{c}}=-\Delta \mathrm{H} / 2.303 \mathrm{RT}+\Delta \mathrm{S} / 2.303 \mathrm{R} \text {. }
$$

The free energy of adsorption $\Delta \mathrm{G}$ was calculated using equation

$$
\Delta \mathrm{G}=-\mathrm{RT} \ln \mathrm{K}_{c}
$$


The slope and intercept of Fig.2 gave thermodynamic entities for $150 \mathrm{ppm}$ and $200 \mathrm{ppm}$ solution. The values of thermodynamic entities are given in Table 4. The negative enthalpy and negative free energy reflect the exothermic and spontaneous nature of sorption respectively.

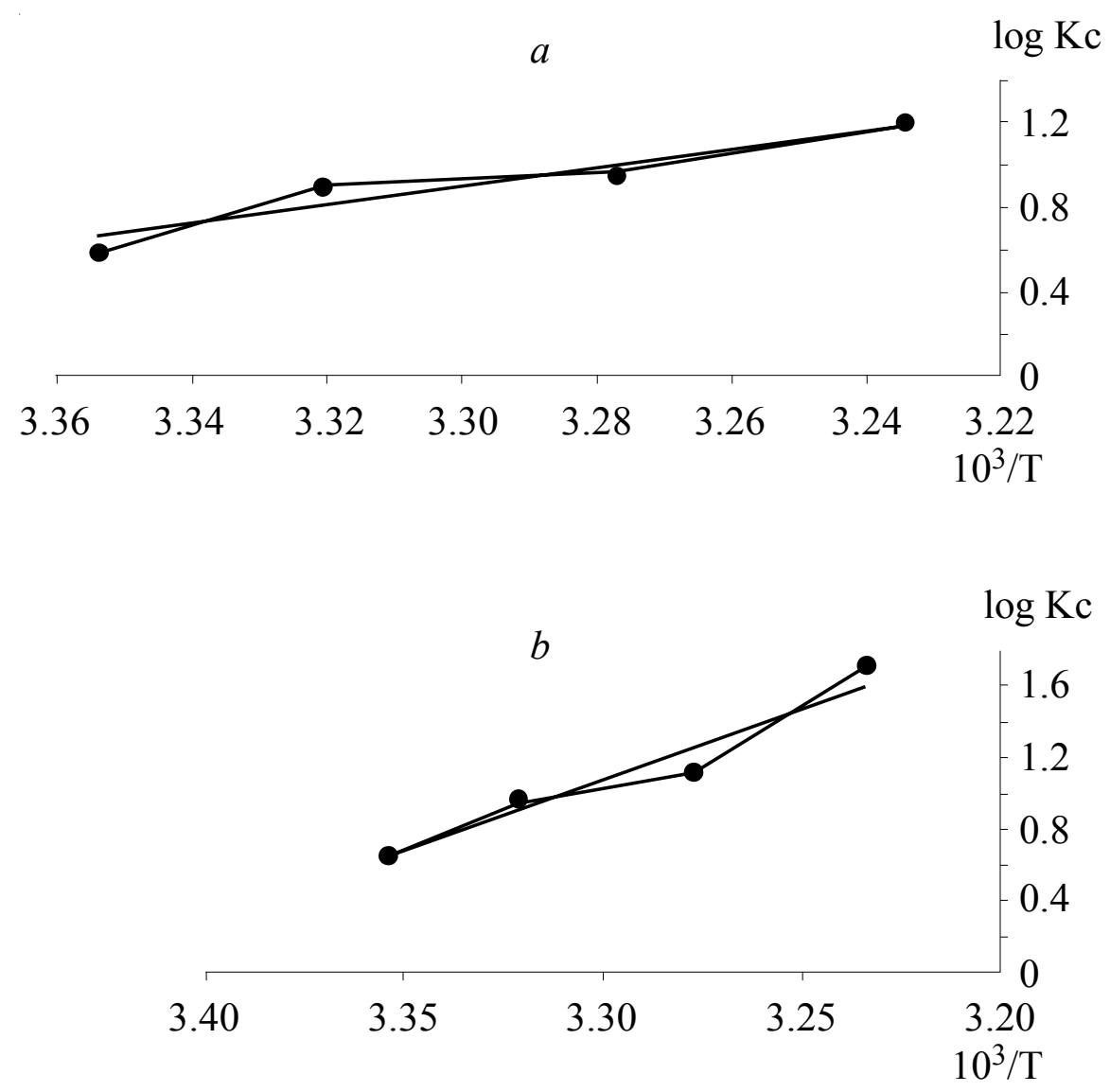

Fig. 2. Removal of Cesium 150 ppm (a) and 200 ppm (b) at different temperature at $\mathrm{pH} 10$.

Table 4. Thermodynamic quantities for sorption of $C s$

\begin{tabular}{|c|l|c|c|c|}
\hline \multirow{2}{*}{$\begin{array}{c}\text { Adsorbing material } \\
\text { packed in } 2.3 \mathrm{~cm} \varnothing \times \\
15.7 \mathrm{~cm} \text { column) }\end{array}$} & $\begin{array}{c}\text { Conc. of Cs } \\
(\mathrm{ppm})\end{array}$ & \multicolumn{3}{|c|}{ Thermodynamic quantities } \\
\cline { 3 - 5 } & & $\begin{array}{c}\Delta \mathrm{H}, \\
\mathrm{KJ} / \mathrm{mole}\end{array}$ & $\begin{array}{c}\Delta \mathrm{S}, \\
\mathrm{J} / \mathrm{mole} . \mathrm{K}\end{array}$ & $\begin{array}{c}\Delta \mathrm{G}, \\
\mathrm{KJ} / \mathrm{mole}\end{array}$ \\
\hline \multirow{2}{*}{ Silica Sand } & 150 & $-27.22 \pm 0.18$ & $-74.1 \pm 0.96$ & $-3031 \pm 2.1$ \\
\cline { 2 - 5 } & 200 & $-20.2 \pm 0.20$ & $-47.86 \pm 0.66$ & $-4288 \pm 3.7$ \\
\hline
\end{tabular}


The results of cesium concentration dependence study on sorbents were also subjected to analysis in terms of Langmuir and Freundlich adsorption isotherms. The data do not fit for Langmuir equation. However Freundlich adsorption isotherm was capable of describing the data over the concentration range studied. The Freundlich isotherm was tested in the following linearized form:

$$
\log \mathrm{C}_{\mathrm{ads}}=\log \mathrm{A}+1 / \mathrm{n} \log \mathrm{C}_{\mathrm{e}} \text {, }
$$

where $\mathrm{C}_{\mathrm{ads}}$ - amount of cesium ion adsorbed at equilibrium (mol/g); $\mathrm{C}_{\mathrm{e}}-$ equilibrium concentration of cesium in the solution $\left(\mathrm{mol} / \mathrm{dm}^{3}\right)$; A and $1 / \mathrm{n}-$ Freundlich constant.

Almost all this adsorptive separation processes depend on physical sorption rather than chemisorptions and this therefore the focus of the present review. The heat of sorption provides a direct measure of the strength of the bonding between sorbate and surface. Physical sorption from the liquid phase is invariably exothermic, although there are very small heat changes, as may be shown by a simple thermodynamic argument. Since the sorbed molecule has at most two degrees of translational freedom on the surface and since the rotational freedom of the adsorbed species must always be less than that of the liquid phase molecule, the entropy change on sorption $\Delta \mathrm{S}=\mathrm{S}_{\mathrm{ads}}-\mathrm{S}_{\mathrm{gas}}$ is necessarily negative. In order for significant sorption to occur, the free energy change on sorption $\Delta \mathrm{G}$ must also be negative and since $\Delta \mathrm{G}=\Delta \mathrm{H}-\mathrm{T} \Delta \mathrm{S}$, this requires $\Delta \mathrm{H}$ negative, or exothermic sorption. Therefore maximum sorption at temperature $\left(36^{\circ} \mathrm{C}\right)$ and low sorption at higher temperature is exactly according to this theory.

Once the cesium has removed from the industrial effluent through sorption then the next step is its stabilization which was achieved by converting the sorbent into the stable and leach resistant glass matrix.

There has much research focused on the composition durability relationship of glass. The glass formers are the major constituents of all waste glasses. If the inorganic oxides present in the silica sand have insufficient glass formers to fall within the accepted formulation range, additional glass formers must be added through the process. The silica sand selected for sorption has suitable composition required to develop a glass frits. The attempt was made to develop different glass formulations by varying composition of modifiers and fluxes based on the calculations. The developed glass frits were characterized mainly focusing on their density and leachibility.

Density was measured on basis of volume displacement method using simple relation of $D=m / v$, where $m$ is mass of glass and $v$ is the volume displaced by sample when dipped in known volume of water. 
In order to rapidly determine the chemical durability of the glass, a leaching test method was derived from the standard PCT leach test method named as M-PCT. The glass sample grinded and attain in the particle size of $1.0-1.2 \mathrm{~mm}$. the sample was washed with the acetone to remove the fine particles before testing. The surface area of the sample was calculated by following equation $[21,22]$ :

$$
\mathrm{SA}=6 \mathrm{M} / \rho \varnothing \cdot 0.89
$$

where SA is the surface area in $\mathrm{cm}^{2}, \mathrm{M}$ the mass ( $\mathrm{g}$ ) of the glass sample, $\rho$ is density $\left(\mathrm{g} / \mathrm{cm}^{3}\right)$ of glass sample, $\varnothing$ is average diameter in $\mathrm{cm}$ and 0.89 is factor to convert the results from sphere particles to glass.

The sample was first leached for 19 hours in an ammonium hydroxide buffer of $\mathrm{pH} 9$, followed by a second leach of 19 hours in an acetate buffer of $\mathrm{pH} 3.9$, both solutions at ambient temperature. After exposure to the buffered solutions, the glass was leached for 24 hours at $99^{\circ} \mathrm{C}$ in deionized water. The leachate of every phase was analyzed using Inductively Coupled Plasma spectrometry (ICP) for the concentration of $\mathrm{Si}, \mathrm{Na}, \mathrm{Al}$ and particularly $\mathrm{Cs}$. The total mass loss of glass (ML) and the normalized elemental loss (NL) were obtained. The ML and NL were used to monitor the chemical durability of glass forms during glass formulations development. The ML value was calculated as follows:

$$
\mathrm{ML}=\left(\mathrm{m}_{\mathrm{o}}-\mathrm{m}_{1}\right) \mathrm{SA},
$$

where ML is total mass (gm) lost, $\mathrm{m}_{\mathrm{o}}$ the mass (gm) of unleached specimen, $\mathrm{m}_{1}$ the mass (gm) of specimen after leaching and SA is the sample surface area $\left(\mathrm{m}^{2}\right)$. Regarding to elemental analysis in leachate, the normalized element mass loss NL was calculated using formula:

$$
\mathrm{NL}=\mathrm{C}_{\mathrm{i}} \cdot \mathrm{V} \cdot \mathrm{SA} \cdot \mathrm{f}_{\mathrm{i}}
$$

where NL is element mass $\left(\mathrm{g} / \mathrm{m}^{2}\right)$ lost, $\mathrm{C}_{\mathrm{i}}$ is the concentration of element $\left(\mathrm{g} / \mathrm{m}^{3}\right)$ in the leachate, $\mathrm{V}$ is the volume of leachant $\left(\mathrm{m}^{3}\right), \mathrm{f}_{\mathrm{i}}$ is the mass fraction of element in unleached glass sample.

Amongst the studied formulations the composition, AG 327 was found excellent in terms of its low leachibility and greater chemical stability. The formulation $\mathrm{AG} 327$ contains $10 \% \mathrm{Na}_{2} \mathrm{O}$ where as the percentage of $\mathrm{Na}_{2} \mathrm{O}$ in studied silica sand was only $1.2 \%$. This difference in percentage of $\mathrm{Na}_{2} \mathrm{O}$ from $1.2 \%$ to $10 \%$ was achieved by adding $15.04 \mathrm{gm} \mathrm{Na}_{2} \mathrm{CO}_{3}$ as source material calculated by the given formula as: 


$$
\mathrm{Wsm}=\mathrm{Wpm} \cdot 100 / \mathrm{Cpm},
$$

where the Wsm is weight (gm) of the source material, Wpm is the required weight (gm) of particular metal oxide and $\mathrm{Cpm}$ is contents of particular metal oxide in used source material. The $\mathrm{Na}_{2} \mathrm{CO}_{3}$ was used as the source material for its alkali metal oxide ( $\mathrm{Na}_{2} \mathrm{CO}_{3}$ gives $58.5 \% \mathrm{Na}_{2} \mathrm{O}$ on thermal decomposition ).

The silica with sorbed cesium was converted to the composition (SG) and was heated at $1250^{\circ} \mathrm{C}$. During melting process the fumes were collected in the cold water. The water was analyzed and cesium traces were found in the water. It indicated that during heating of the matrix at temperature $1250^{\circ} \mathrm{C}$, cesium was evaporated. To overcome this problem, the silica along with the sorbed cesium was first mixed with calculated amount of $\mathrm{Na}_{2} \mathrm{CO}_{3}(15.04 \mathrm{~g})$ and was heated at $500^{\circ} \mathrm{C}$ and cooled. The vitreous material obtained in this result was converted into a composition (SG) and was melted at $1250^{\circ} \mathrm{C}$. The fumes during melting were collected in the cold water. The water was analyzed for cesium traces and there was no cesium found in the water. The end product has excellent glass appearance without bubbles and any crack.

\section{Conclusion}

Silica sand, a cheaper and abundantly available material, was proved to be an excellent sorbent for sorption of cesium from aqueous solutions under certain physiochemical parameters. The maximum sorption can be obtained at $36^{\circ} \mathrm{C}$ in basic media ( $\mathrm{pH} 10)$. The negative value of $\Delta \mathrm{H}$ and negative value of $\Delta \mathrm{G}$ show the exothermic and spontaneous nature of sorption respectively. The maximum sorption at $36^{\circ} \mathrm{C}$ supports the exothermic nature of sorption. The lower sorption at higher acidic concentration and lower $\mathrm{pH}$ values may be due to the competition between the positively charged cesium and $\mathrm{H}^{+}$. The lower sorption at higher $\mathrm{pH}$ might be due to the surface complexation phenomenon, which is facilitated by the dissociation of surface functional groups. The silica sand was proved a best glass forming material as it contains almost all basic component required to develop a good quality glass. The composition of the silica sand was modified to suitable composition by adding small amount of $\mathrm{Na}_{2} \mathrm{O}$. To overcome the evaporation of cesium during heating, silica having sorbed cesium was first mixed with the calculated amount of $\mathrm{Na}_{2} \mathrm{CO}_{3}$ and heated at $500^{\circ} \mathrm{C}$ and cooled to room temperature. Later on, this vitrous material was converted into the composition (SG) and was melted at $1250^{\circ} \mathrm{C}$ and the glass matrix was achieved. The leachibility test was performed in both acidic and basic media which was ignorable. A comparative experimental data obtained in this study reveals that silica sand may be employed for the removal and stabilization of cesium from aqueous industrial effluents before discharging them into water bodies. As the silica sand is a good sorbent for other heavy 
metals also therefore this technique may be applied for removal and stability of other heavy metal ions as well.

\section{References}

[1] Robards K., Worsfold P. //Analyst, 1991,116, P.549.

[2] Miller G.T., Jr. Living in the environmental concepts, problems and alternatives. Berlmont: Wadsworth publishing company Inc., 1975.

[3] Alan. S.H. The Encyclopedia Americana, 1984, 12 (4), P.451 - 461.

[4] Hathaway G.J, Proctor N.H., Hughes J.P., Fischman M.L. Proctor and Hughes' chemical hazards of the workplace/3rd ed. - New York: Van Nostrand Reinhold, 1991.

[5] ACGIH [1991]. Documentation of the threshold limit values and biological exposure indices. 6th ed. Cincinnati, OH: American Conference of Governmental Industrial Hygienists.

[6] ACGIH [1994]. Threshold limit values for chemical substances and physical agents and biological exposure indices. Cincinnati, $\mathrm{OH}$ : American Conference of Governmental Industrial Hygienists.

[7] Avila D., Matos J.P., Cavalcani I., Andrade J. // Water Sci. and Technol, 1991, 24(12), P.159 - 164.

[8] Shang Lein P.J., Chi-Ying T.A. // Environ. Eng., 1991, 12 (4), P. 451 - 461.

[9] Wolfgang J., Felgener F.A., Gerd W. //Water Res., 1992, 30, P. $2609-2620$.

[10] Brain E., Thomas Q., Bob S. // Study on Heavy Metals Accumulation. ProcAnnu. Int. Pittsbugh coal conf, 12th, 1995, P. 358 - 363.

[11] Liang F., Ji-Yann H., Lin Hong-Chi K.H. // J. Environ. Sci., 1999, 37 (3), P. $412-419$.

[12] Suyama G., Takazo M., Palavinal M., Dessouki Z.B. // J. Environ. Sci. Health Part (A), 1995, 28 (1), P. 37 - 50.

[13] Ahmed S., Qureshi I.H. // J. Environ. Anal. Chem., 1991, P. 44, 257.

[14] Khalid N., Rahman A., Ahmed S. // Radiochim. Acta., 1998, 83, P. 157 - 162.

[15] Sheng J., Choi K., Yang K., Lee M., Song M. // Nucl. Technol., 2000, 129, P. 246.

[16] Sheng J., Luo S., Tang B. // Ibid, 1999, 125, P. 85.

[17] WSRC-MS-97-0051. Glasses formation, development and testing for the vitrification of oak ridge tank waste.

[18] Bansal R.C., Donnet J.B., Stoecki F. Active Carbon. Marcel Dekker Inc., 1988.

[19] Rivin D., Kendrick C. // Carbon., 1997, 35, P. 1295 -1305.

[20] Liang // Radiochim. Acta., 1992, 76, P. 163 - 172.

[21] Choi K., Sheng J., Song M. Development of modified product consistency test (M-PCT) /Korean Nuclear Society Spring Meeting (Seoul, Korea, May 14-15, 1998).

[22] Norbert H.M., Heinrich M., Rudolf W. // Glass Sci. Technol., 1999, 72 (8), P. 266. 